\title{
A EVOLUÇÃO DAS MÁQUINAS DE BENEFICIAR CAFE NO BRASIL
}

\author{
Prof. Dr. HUGO DE ALMEIDA LEME \\ Catedrático de Mecânica e Máquinas Agrícolas \\ Escola Superior de Agricultura "Luiz de Queiroz" \\ Universidade de S. Paulo - Piracicaba
}

\section{INDICE}

Descascamento manual . $\ldots \ldots \ldots \ldots \ldots$

Pilão $\ldots \ldots \ldots \ldots \ldots$

Descascamento por meio de varas $\ldots \ldots \ldots \ldots$

Descascamento por piso de animais ... . . . . . . . . . . . 7

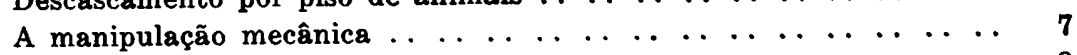

$\begin{array}{llllllllllllllllllll}\text { Monjolo } & \ldots & \ldots & \ldots & \ldots & \ldots & \ldots & \ldots & \ldots & \ldots & \ldots & \ldots & \ldots & \ldots & \ldots & \ldots & \ldots & 8\end{array}$

Pilão d'água $\ldots \ldots \ldots \ldots$

Máquinas movidas a tração animal . . . . . . . . . . . . . 11

Monjolo de rabo . . . . . . . . . . . . . . . . . . . . . 12

Carretão $\ldots \ldots \ldots \ldots \ldots$

Máquina de descarga contínua $\ldots \ldots \ldots \ldots \ldots$

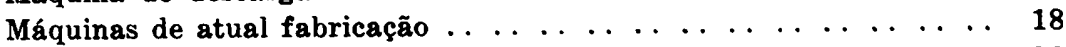

Bibliografia $\ldots \ldots \ldots \ldots \ldots$ 
No passado da nossa evolução econômica, o café, pelo seu volume e real valor, constituiu uma das pedras angulares do edifício econômico do Brasil, a ponto de podermos afirmar, não obstante as oscilações verificadas em sua trajetória evolutiva, que a economia nacional, encarada sob diversos aspectos, muito deve ao produto agrícola, que ainda é uma das pricipais fontes canalizadoras de ouro para os cofres nacionais. Incontestàvelmente, o café mantém-se na linha dos produtos líderes da nossa grandeza econômica e nunca será inoportuna a palavra significativa e feliz de Lyra Castro (1), ou seja, - "quem diz café, diz riqueza brasileira".

Decorre dessa assertiva a necessidade que sempre tivemos de cuidar com carinho do melhoramento dêsse produto, a fim de que possa competir satisfatòriamente com o de outras procedências. Vence nesta luta o produto que reune em si um conjunto de qualidades imprescindíveis, as quais, em resumo, são resultantes da correta execução das operações desde a formação do cafèzal até a colocação do produto no mercado.

Afora o melhoramento do cafeeiro, obtido mediante seleção, adubação, etc., há a considerar como fator preponderante no aperfeiçoamento do produto, a melhoria do Beneficiamento. E' fácil compreender como o Beneficiamento influi na obtenção de produto de qualidade superior. Suponhamos um cafèzal que haja sido formado em obediência a todos os requisitos técnicos, ou seja, em terras idealmente situadas que preencham tôdas as condições exigidas pela preciosa Rubiácea, com sementes selecionadas oriundas de inúmeros anos de trabalho genético, e no qual tôdas as operações culturais são realizadas caprichosamente. Enfim, um ótimo cafèzal. Sendo assim, e considerando ainda uma colheita cuidadosa, obter-se-à forçosamente um produto o melhor possível. Entregue-se agora êste café em côco ao Beneficiamento, o qual venha a ser realizado por Máquinas imperfeitas, mal reguladas, que não separem as impurezas, não descasquem, mas quebrem, que tinjam os grãos, em sintese, que maleficiem o produto ao invés de beneficiá-lo. De uma seriação de operações tais, o resultado é indiscutível : produto de péssima cotação, ou seja, anulação de todos os trabalhos anteriores ao Beneficiamento pròpriamente dito.

Não é portanto demais insitir que o bom êxito da cafeicultura não depende tão sòmente do solo, do cafeeiro, do processo de cultura, da melhor colheita, mas também, em grande parte,

(1) Lyra Castro - A trajetória história do café - Pág. 48. 
do preparo do produto, ou em outras palavras, das Máquinas de Beneficiamento.

Assim sendo, e como não podia deixar de ser, no Brasil, a evolução das máquinas de Beneficiar café foi considerável e rápido, passando por uma sèriação de modificações, desde o primitivo processo manual ao emprêgo das modernas máquinas fabricadas em nosso País.

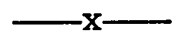

No estudo do histórico das Máquinas de Beneficiamento pròpriamente dito do café diremos, preliminarmente, que o desenvolvimento dessas máquinas acompanhou o progresso da cafeicultura.

\section{DESCASCAMENTO MANUAL}

Inicialmente, nas primitivas e pequenas plantações, o café, após a secagem ao sol, era, no Brasil, descascado manualmente. Para êste fim, colocava-se o produto sôbre uma grande mesa, e aí os escravos dispostos ao redor dessa peça procediam o descascamento. Consistia a operação em manter os grãos entre as palmas das mãos, apertá-los e simultâneamente a êsse ato submetê-los a movimentos de friç̧ão. Observemos que essa operação, ou melhor, o preparo do café por processo manual era realizado pelas mulheres, enquanto que os negros destinavam-se ao trato das culturas (1).

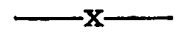

Sendo maior o plantio, não resta a menor dúvida que então o Beneficiamento do café passou a ser realizado no rústico e simples pilão, por meio de varas, ou quando não por piso de animais, processos êsses que passamos a examinar.

\section{PILAO}

O pilão foi um dos utensílios mais generalizados e usuais no Beneficiamento do café em nosso País.

Era constituido por um simples tôco de madeira, grosso, verticalmente disposto, tendo na parte superior uma cavidade ou bojo de fundo concavado, de secção circular - diâmetro de

(1) Assis Cintra - Origem do maquinário do café - pág. 1081. 
40 a $50 \mathrm{~cm}$ e de 60 a $80 \mathrm{~cm}$ de profundidade. Para que oferecesse melhor aspecto a peça era entalhada (fig. 1).

Uma haste de madeira resistente, de um metro de comprimento mais ou mencs e diâmetro de 10 a $12 \mathrm{~cm}$, pouco mais delgada na parte média, completava o pilão. Esta peça, de medidas variáveis com a campleição do operário, denominava-se mäo de piläo. café.

Com o conjunto - pilão e mão de pilão - descascava-se o

Eis como se realizavam e se sucediam as operações : várias escravas (ou escravos) distribuiam-se em grupos de dois ou três em tôrno dos pilōes de madeira (1).

Enchiam de café em côco secado convenientemente o bojo do pilão, e então, alçando as pesadas mãos de pilão à altura máxima que lhes permitia o movimento, faziam-nas cair com energia, em conjugação de esforços, sôbre o café. $\mathrm{E}$ assim operavam até descascá-lo. Concluida essa operação, passavam a abanar o produto em peneiras de taquara, catando, enfim, os marinheiros, (sementes ou favas com pergaminho - endocarpo) - e os côcos, que retornavam ao pilão. E a operação se repetia (Fig. 2).

O piloamento do café era trabalho árduo e de pequeno rendimento. Hildebrando de Magalhães assim o comenta :

"A tarefa de beneficiar o produto no pilão, manualmente. era na realidade por demais penosa. Os pretos que nela se empregavam, absorviam sem cessar o pó do café que lhes cobria o rosto, a carapinha, e mesmo o torax em densa camada" (2)

\section{DESCASCAMENTO POR MEIO DE VARAS}

$\mathrm{Na}$ época em que se usava pilar o café, já estava muito em. voga o processo de descascamento por meio de varas (Fig. 2).

Constava do seguinte: $O$ café em côco, secado convenientemente, uma vez no chäo do depósito, ou do próprio terreiro socado e varrido, era malhado, ou melhor, surrado, pelos escravos, com simples varas de madeira, tal como se faz para descascar o feijão (3). Outro expediente consistia em empregar varas articuladas, mangual ou camböes (4), formadas por duas

(1) Augusto Ramos - Máquinas primitivas de beneficiar café pág. 76.

(2) Hildebrando de Magalhães - História do café - pág. 117.

(3) Pe. João J. Ferreira de Aguiar - Pequena memória sôbre a plantação, cultura, e colheita do café - Pág. 15.

(4) Bernardo Sayão de Carvalho - A evolução do beneficiamento Pág. 152. 
hastes - mango e pirtigo - ligadas por meio de tiras de couro. Descascado o café, procedia-se à abanação em grandes peneiras de taquara. As cascas eram assim separadas. A catação dos grãos não descascados, o que se realizava para obter o produto comerciável, completava o beneficiamento.

As desvantagens do processo são palpáveis, sendo suficiente dizer-se que, além de ser rústico, de baixo rendimento $e$ exaurir o laborioso escravo, dava um produto de péssima qualidade.

\section{DESCASCAMENTO POR PISO DE ANIMAIS}

Em determinadas propriedades substituia-se o piloamento pelo descascamento por piso de bois (Fig. 3), o qual consistia no seguinte: esparramava-se o café num chão sêco, socado e varrido. Depois, durante os dias insolarados, cinco, oito ou dez bois eram compelidos a passar em idas e vindas nesse local. Com isso, no término do dia o café se apresentava desmembrado em palhas e sementes (1). Retirava-se, então, dêsse local, um misto encardido de café e terra, que logo era abanado pelas escravas.

Completada a abanação e em sequência a catação dos marinheiros, o produto estava em condições de ser entregue ao mercado.

\section{A MANIPULAÇÃO MECÂNICA}

Com a contínua expansão da cafeicultura, acrescida da concorrência comercial instigando o fornecimento de produto melhor preparado e mais barato, o modesto e arcáico processo arábico, ou melhor abexim (2), de piloamento e outros processos descritos já não eram compatíveis com o adiantamento técnico-agrário, bem antes do fim do século XVIII. Embora o braço escravo fosse abundante, havia a necessidade de substituí-lo por máquinas, não só para atender o volume crescente da nossa produção mas também para a obtenção de um produto apto a concorrer com o de outras procedências. A concorrên-

(1) Assis Cintra - Op. Cit. - Pág. 1082.

(2) Affonso de E. Taunay - Beneficiamento dos cafés coloniais Pág. 2586. 
cia em tipos ainda não existia, porém, já se fazia sentir a necessidade de valorizar o produto melhorando o seu aspecto.

Urgia sair-se do empirismo em que se encontrava o preparo do nosso principal produto. Foi então que começou a tomar vulto o interêsse pela manipulação mecânica. Esse surto progressista inaugurava um novo período na história do Beneficiamento do café.

Os cafeicultores brasileiros começaram a construir e empregar as primeiras máquinas, imitando as já existentes noutros países, quando não, inventando-as. Apareceram então dois grandes grupos: o das Máquinas movidas a fôrça hidráulica e o das Máquinas de tração animal.

A primeira máquina, representante do grupo das movidas pela fôrça hidráulica, que teve, aliás, grande aplicação no Brasil, foi o Monjolo.

\section{MONJOLO}

Esta máquina (Figs. 4-5), acionada por pequena queda d'água, possuia em linhas gerais a seguinte constituição:

Uma longa e roubusta prancha - marmaz - de madeira de lei (Fig. 5-a), nesse tempo abundante, e comumente de cabreúva (Myrocarpus fastigiatus, Fr. All.), era atravessada por pequena cavilha - tranqueta (1), apoiando-se assim na cabeça de um suporte - virgem ou pasmado c, de bôa e resistente madeira, cravado firmemente no solo. Compreende-se que a prancha, tendo como ponto de apôio a virgem, funcionava como alavanca interfixa. Numa das suas extremidades havia um côcho - colher - $d$, medindo um a dois metros mais ou menos de comprimento. $\mathrm{Na}$ outra, denominada munheca, fixava-se um soquete ou mão b de madeira - diâmetro de 10 a $15 \mathrm{~cm}$, em posição perpendicular, cuja função era a de socar o café no bojo de um pilão. Este, construido com tôco de madeira, mantinha-se implantado no chão.

O monjolo apresentava uma particularidade interessante em sua construção. $O$ braço do soquete, sendo mais pesado que - côcho, conservava-se em descanso no bojo do pilão desde que - côcho estivesse vazio. Geralmente, para conseguir efeito mais eficaz do monjolo, colocava-se um contrapêso no braço do soquete. Esse contrapêso recebia o nome pitoresco de macaco.

(1) Affonso de E. Taunay - Subsídios para a história do café no Brasil - Pág. 415. 
Em virtude da sua constituíção a máquina era montada sob pequena queda d'água, e de tal modo que o líquido, encaminhado por uma bica de madeira, vinha cair no meio do côcho.

De posse dêsses conhecimentos, vejamos como funcionava o monjolo. Depositava-se o café no bojo do pilão, até quase enchê-lo, retirava-se a haste de madeira - estronca - que especava o monjolo, soltava-se a água para que enchesse o cócho e aumentasse o momento dêsse braço. $\mathbf{E}$ a operação tinha início. A máquina rangia; a prancha oscilante inclinava-se e cum isto a extremidade armada do soquete subia descrevendo um arco de círculo Com a inclinação, a água do côcho vasava para o inferno (receptáculo), e então, em consequência do maior momento do outro braço, produzia-se rápido movimento inverso, vindo a mão ou soquete atritar com energia o café uxistente no pilão. Tornava o côcho a encher-se de água e a operação se repetia, duradoura, lenta e cadenciadamente, até o completo descascamento do café.

Alcançado êste objetivo parava-se a máquina por intermédio da estronca; interrompia-se a passagem da água; retiravase o café, abanava-se e finalmente procedia-se a catação dos marinheiros, e o produto era entregue ao mercado.

A aplicação dessa máquina antiquada - de procedência chinesa conforme demonstra Varnhagen - no preparo do café, evidenciou um notável progresso.

Seja lá como for, o piloamento do café, antes manual, passára a ser operação mecânica, embora se diga que o rendimento do monjolo era pouco mais de $10 \%$ e que a abanação persistia manual, árdua e ocasionadora de grande quantidade de pó sumamente nocivo à saúde dos escravos.

Alargando-se os horizontes da cultura cafèeira os mesmos fatôres, determinantes da transição do processo manual para a manipulação mecânica, ora de repercussão mais profunda, instigavam novos rumos no beneficiamento do café. Neste novo passo da evolução em esbôço coube às monografias, então existentes sôbre a cafeicultura, desempenhar um papel importante no ambiente criado por aquêles fatôres. De passagem, citemos alguns dêstes trabalhos, ou sejam: "A arte da cultura e preparação do café", de Augustinho Rodrigues Cunha; "Pequena memória sôbre a plantação, cultura e colheita do café", de Pe. João J. Ferreira Aguiar; "Do café considerado no sentido de sua colheita, de sua lavagem, e da sua maneira de secá-lo para conservar", de G. Constant; "Memória sôbre um novo método de preparar o café", de Antonio Silveira Caldeira; e "Monografie du café", de G. E. Coubard - D'Aaulnay. 
Foi sob o influxo das idéias ventiladas por êsses e outros trabalhos, e mais, da necessidade de melhorar o produto, imposta pelas circunstâncias conhecidas, que se aperfeiçoaram as máquinas empregadas no seu preparo.

Com efeito, nos fins do século XVIII e princípios do século XIX, o cafeicultor começa a utilizar outros tipos de máquinas, mais eficientes, em suma, de maior e melhor produção. Assim é que em princípios do século XIX alguns dêles adotam o polimento (brunimento) do café, pilando novamente o produto descascado, prática não muito recomendável (1). O pilão foi, portanto, o primeiro polidor (brunidor) empregado. A abanação já se apresentava parcialmente mecanizada, visto que a separação da palha era feita em ventilador centrifugo de palhetas planas conjugado a u'a caixa com moega e bica de descarga, tal como preconiza Augustinho Rodrigues Cunha (2).

A catação do marinheiro continuava a ser realizada com destreza pelas escravas, em peneiras então chamadas de sururuca ou poruca (3). Essa operação denominada sururucar era completada pela catação a dedo, ambas feitas pelas escravas, as quais catavam, em média, de 45 a $60 \mathrm{Kg}$ por dia.

Das inovaçōes introduzidas surgiram as máquinas ajustadas à roda d'água, a qual há tempos tinha largo uso nos engenhos de fabricação de açúcar (4). E dêste modo foi que o pilão d'água, ou engenho de pilöes ou pilöes mecânicos, passou a ser empregado no beneficiamento do café brasileiro.

\section{PILAO D'AGUA}

O pilão d'água (Figs. 6-7) constava de uma roda d'água de dimensões variáveis conjugada geralmente a um rodete dentado, o qual transmitia o movimento circular à roda dentada de um eixo armado de tangedeiras (a tangedeira nada mais era do que uma pequena peça de madeira fixa no eixo da roda dentada). Quando não havia êste dispositivo, substituía-o o eixo da própria roda d'água. Esse eixo operava numa sólida armação construida de cabreúva, ou de peroba (Aspidosperma spp), ou

(1) Pe. João J. Ferreira de Aguiar - Op. Cit. — Pág. 14.

(2) Augustinho Rodrigues Cunha - A arte da cultura e preparação do café - Pág. 88.

(3) Affonso de E. Taunay - Subsídios para a história do café no Brasil - Pág. 416.

(4) André João Antonil - Cultura e opulência do Brasil - Pág. 196. 
ainda de braúna ou barauna (Melanoxylum braúna Schot), tendo as vigas secção de $50 \times 50 \mathrm{~cm}$ e 4 a $5 \mathrm{~m}$ de altura, mais ou menos. Na base da armação, ou pouco acima, assentava-se um côcho alçapão, de fundo removível.

Pesadas mãos de pilão (Fig. 6), em número cocordante com a energia disponivel, passando com certa folga pelos furos correspondentes de duas travessas de madeira, cuja função era a de mantê-las verticalmente, constituíam as peças operantes responsáveis pelo descascamento. Em geral, possuiam cabeça ovóide com chapeamento de bronze ou ferro, ou forma tronco piramidal de ferro fundido, não muito preconizada, pelo incoveniente de quebrar o café.

Duas pequenas peças de madeira - as aspas, e um pequeno furo para ajustagem do espigão de ferro, existiam, individualmente, nas mãos de pilão. Essa última peça complementar permitia especá-las uma vez concluido o descascamento do café.

Funcionamento - Movimentada a roda d'água esta acionava o eixo, e em sequência, as tangedeiras e as aspas transformavam o movimento circular contínuo em retilíneo alternativo, isto é, o de alçar e deixar cair as pesadas mãos de pilão. Algum tempo depois, o café depositado no côcho estava em condições de ser ventilado.

Descascado o café, interrompia-se o movimento ajustando os espigões nos respectivos furos das mãos de pilão. Retiravase então o produto e colocava-se-o em ventiladores manuais ou mecânicos para a necessária eliminação da palha (cascas). Completava-se essa operação com a de sururucar. Certos cafeicultores poliam (bruniam) ainda o café em moinhos de pedra semelhantes aos de fubá (1), ou em pilōes, depois do que procediam a catação das escôlhas (café chocho, quebrado, etc.).

\section{MAQUINAS MOVIDAS A TRAÇÃO ANIMAL}

O emprêgo destas máquinas acompanhou o do pilão d'água. Caraterizavam-nas os diferentes tipos de almanjarras, também denominadas atafonas ou manejos.

Dava-se assim mais um passo no aperfeiçoamento das máquinas de beneficiar café, e dentre as quais predominou o carretão, a ponto de ser ainda usado em algumas propriedades de certas regiöes do Brasil.

(1) Augustinho Rodrigues Cunha - Op. Cit. - Pág. 89. 


\section{MONJOLO DE RABO}

Foi em Campinas, talvez mais ou menos em 1830, por genial invenção possivelmente de algum mecânico, que surgiu êsse tipo de monjolo dotado de apêndice caudal de pitoresco aspecto. Neste o motor animal substituia o propulsor hidráulico do monjolo pròpriamente dito (1).

Três ou quatro dêstes monjolos distribuíam-se em volta do suporte da almanjarra. Um cavalo ou um boi movimentava a almanjarra, a qual fazia com que a bateria conjugada dos monjolos de rabo caisse sucessivamente nos cochos dos pilões. $O$ quadro de Alfredo Norfini (fig. 8) permite apreciar melhor êsse mecanismo e de como podia funcionar.

\section{CARRETAO}

O carretão, ribas, ripes ou rodeio (Fig. 9), constituiu no inicio do século XIX a principal máquina de tração animal usada no preparo do café. Examinemos, pois, a sua constituição e o seu funcionamento.

Um mourão ou suporte - pião - (2), implantado sòlidamente no chão, justamente no centro de uma coroa que nada mais era do que um côcho circular de madeira - calha -, servia de apôio a um robusto eixo de madeira lavrada, e ás vezes até a mais de um. Ajustavam-se neste eixo as seguintes peças :

- Pesada roda de madeira - rigola - , de 2 a $2,50 \mathrm{~m}$ de diâmetro e 20 a $25 \mathrm{~cm}$ de espessura, a qual rolava dentro do côcho;

- Grande garfo de madeira, situado logo atrás da roda, destinado a remexer o café machucado pela mesma;

- Pequena boléia para o condutor dos animais;

- Finalmente, os balancins.

$\mathrm{Na}$ construção desta máquina era frequente o emprêgo de uma das seguintes madeira: cabreúva, peroba, garabú ou garapa (3) (Apulleia praecox Mart.) e o pau d'arco (Tecoma heptaphylla Mart.).

(1) Affonso de E. Taunay - Subsídios para a história do café no Brasil - (Volume II) - Pág. 378.

Três ou quatro dêstes monjolos distribuiam-se em volta do

(2) Raphael P. de Miranda - Cultura do café na Baía - Pág. 66.

(3) C. F. van Delden Laèrne - Le Brasil et Java. Rapport sur la culture du café - Pág. 277. 
Compreende-se, pelo exame da própria estrutura do carretão, que a pesada roda, animada de movimento de rotação em relação ao eixo, e de outro de translação, relativamente ao suporte, rodava no côcho, a passos tardos dos ruminantes, atritando e desmembrando o café em sementes e cascas. Um escravo sentado na boléia (Fig. 9) conduzia os animais, e outro manejando o garfo ia remexendo o café.

Após, de ordinário, pouco mais de duas horas de contínua ação do carretão, parava-se a máquina; retirava-se o produto e lançava-se-o no soprador (ventilador) ou então procedia-se à sua abanação, ao que seguia a catação manual. Os marinheiros e os côcos retornavam ao carretão, completando-se assim o preparo das sementes.

A capacidade do carretão, variável com suas dimensões, era de mais ou menos, em caso comum, $750 \mathrm{Kg}$ de café descascado em 12 horas de trabalho.

O carretão experimentou, em determinadas regiões do país, alguns aperfeiçoamentos, dentre os quais citamos a introdução de engrenagens e chumaceiras de bronze. Já em vários países da América (1) a evolução foi mais acentuada, a ponto de ainda ser utilizado tal como o que se vê na Fig. 10.

\section{MAQUINA DE DESCARGA CONTINUA}

Ante o que apreciamos, nas páginas anteriores, podemos dizer que a maquinaria de beneficiar café apresentava um aperfeiçoamento bem notável relativamente à dos primitivos processos, nos meados do século XIX. Na sua construção tornava-se comum o emprêgo de madeira de lei, resistente, e algumas ferragens. $O$ custo da mesma não era oneroso, pois que, excetuando o preço da ferragem, contava-se com a barateza da mão de obra que era o próprio escravo. Mas até quando perduraria essa situação? Aproximava-se o momento inicial de uma verdadeira mudança no panorama da mecanização do beneficiamento do café. Acentuava-se cada vez mais a necessidade da introdução de melhores máquinas. Patenteava êsse estado de cousas a substituição, embora vagarosa que já se vinha fazendo, da madeira por peças metálicas, o que até certo ponto refletia o espírito progressista dos cafeicultores ansiosos por melhor e maior produção com o mínimo de despesas e no mínimo de tempo.

(1) C. F. van Delden Laèrne - Le Brasil et Java. Rapport sur la culture du café - Pág. 277. 
Não padece a menor dúvida de que nessa época o descascamento estava mecanizado, por uma ou por outra forma, seja pelas máquinas descritas ou seja pelas resultantes destas por pequenas modificações conforme insiste o "Auxiliador da Indústria Nacional", em seu número de setembro de 1853.

A abanação deixara de ser manual para ser realizada por ventiladores, dadas as vantagens inerentes a seu emprêgo. A êste respeito, comenta Burlamaque: "Com um ventilador, um homem faz o serviço de dezesseis a vinte trabalhando com peneira" (1).

A expansão da cafeicultura, porém, não cessa. A instigan. te ação dos fatôres observados acentua-se cada vez mais. $O$ braço escravo vai-se encarecendo, e, como que contrastando êsse evoluir, a operação de preparar o café ainda é penosa, muitı. embora se diga que a mecanização firmava raízes no terreno da maquinaria de beneficiamento do precioso fruto. São oportunas as palavras de Augusto Ramos (2), referentes a êsse estado, às quais transcrevemos:

"O Serviço de beneficiar café era penosíssimo, assim como era igualmente em larga escala o de auxiliar as imperfeitas máquinas daquêle tempo. $\mathrm{E}$ todo êle era feito por pretos escravos, em cujo rosto e cabeleira, se acumulava durante o trabalho tão grossa camada de pó que impossivel era reconhecê-los.

O trabalho começava às 4 horas da manhã e se prolongava até às $\mathbf{9}$ horas da noite, com duas horas apenas de repouso. Muito antes de clarear o dia, já se fazia ouvir o ruído característico daquelas rústicas instalações construidas de madeira, tangendo, rinchando, estalando, mas caminhando sempre na monotonia da tristonha marcha, entrecortada pelo grito espaçado dos "candieiros" ou condutores da boiada".

Essa situação era propícia à introdução de novas máquinas, o que se verificou mais ou menos entre 1859 e 1860, com o aparecimento das máquinas de descarga contínua acionadas por motor hidráulico. Essa época marca o início da verdadeira revolução no terreno da mecanização do preparo do café.

Em 1859, Guilherme van Vleck Lidgerwood, que viera dos Estados Unidos da América do Norte, notando em Campinas o desenvolvimento extraordinário da cafeicultura, aí montou uma oficina para fabricar máquinas de beneficiar café. Inicia-se assim, por essa altura ou pouco depois, a importação e a fabricação de novas máquinas.

(1) F. S. Burlamaque - Monografia do cafeeiro e do café - Pág. 43.

(2) Augusto Ramos - Máquinas primitivas de beneficiar café - Pág. 77. 
Quer nos parecer que cabe a Guilherme van Vleck Lidgerwood o mérito de ter sido o introdutor do beneficiamento racional em nosso país.

Hildebrando de Magalhães (1), citando o parecer de André Rebouças e Antonio de Paula Freitas, parecer êsse publicado no "Auxiliador da Indústria Nacional" (Volume XXXIV) Rio de Janeiro, 1871 - Pág. 60), vem demonstrar a nossa observação. Para melhor esclarecimento destacamos dêste, os seguintes trechos:

“A secção de machinas e aparelhos da Sociedade Auxiliadora da Indústria Nacional, vem cumprir o dever de dar o parecer sôbre a petição de 16 de Novembro de 1870, em que Guilherme van Vleck Lidgerwood requer privilégio por 20 anos para importar, fabricar, usar e vender machinas de café de sua invenção, já privilegiada por Decretos ns. 3.006 de 1862, e 4.319 de 1869 , e nos quais acaba de fazer importantes melhoramentos...

A Seç̧ão de Machinas e aparelhos da Sociedade Auxiliadora da Industria Nacional é' pois de parecer que não cumpriria completamente o seu mandato si se limitasse a dizer que a petição é digna de favorável deferimento e si deixasse passar a oportunidade de levar ao conhecimento do Governo Imperial, que o ilustre e incansável introductor da preparação mechanica do nosso primeiro producto agricola, tem feito jús a uma recompensa nacional mais significativa do que uma simples concessão de privilégio - Sala de Sessões, em 15 de Dezembro de 1870 ".

E ainda o seguinte :

“O café preparado nessas machinas (Máquinas Lidgerwood, então aperfeiçoadas) (2) vende-se 400 a 600 réis mais caros em arroba; são, pois, centenas de contos de réis, que annualmente economizam os nossos agricultores, a-

(1) Hildebrando de Magalhães - Op. Cit. — Pág. 128.

(2) Esta observação é nossa. 
lém dos benefícios que produzem as machinas poupando a vida dos escravos, que no antigo systema dos pilöes eram sacrificados pelo asphyxiante pó de café" (1).

Entraram portanto em uso, de 1860 a 1880, várias máquinas de descarga contínua constituidas por descascadores, ventiladores e separadores de peneiras rotativas de cobre. Estas peneiras, de grandes dimensões, classificavam o café em chato, chatinho e moca, o que valorizava o produto (2).

Lidgerwood, por Decretos de 1862, 1869 e 1872, obteve três privilégios. Guilherme Mac-Hardy, natural da Inglaterra, que trabalhou nas oficinas de Lidgerwood em Campinas, deixando estas oficinas, iniciou em 1870 a fabricação das máquinas que têm o seu nome. Na mesma cidade de Campinas, Arens, logo após Mac-Hardy, fundou também a sua indústria. Na Bahia, Antonio dos Santos, em 1868, sob a orietação do mecânico John Sperling, deu início à fabricação de máquinas (3). No Rio de Janeiro, o número de fabricantes foi elevado. Em resumo, depois da introdução das máquinas de Lidgerwood e da importação das de Albion Coffee Huller \& Cia., surgiram máquinas a barda.

Foi por êsse modo que começou, em fase de verdadeira experiência, a introdução de máquinas pròpriamente ditas de beneficiar café. Dissemos de experiência e isto se compreende fàcilmente, notando-se, que si aquelas não funcionavam a contento, o fazendeiro as devolvia, e com isto surgiam novas modificações nos tipos seguin'es. Embora se observassem tais fatos, o emprêgo das novas máquinas era notável e progredia.

Para que se tenha idéia melhor do desenvolvimento ou expansão das então máquinas de beneficiar café, de descarga contínua, em 1883, citamos os nomes e os números das máquinas usadas por 1.277 produtores de café, somados de 22 municípios brasileiros que tomaram parte na 2a. Exposição de Café do Brasil (4).

(1) Hildebrando de Magalhães - Op. Cit. - Pág. 116.

(2) Nicolau Joaquim Moreira - Breves Consideraçōes sôbre a hist6ria e cultura do cafeeiro - Pág. 50.

(3) Assis Cintra - Op. Cit. - Pág. 1082.

(4) Centro de Lavoura e Comércio - Segunda Exposição de Café no Brasil - 1883. 


\begin{tabular}{|c|c|c|c|c|c|}
\hline \multirow{2}{*}{ VIQUIIIIS } & \multicolumn{5}{|c|}{ PROVINCIAS } \\
\hline & Isp. Sant & Illans genls & 2. It lanein & S. Pand & Inhl \\
\hline $\begin{array}{l}\text { ão } \\
\text { d'água } \\
\text { lo }\end{array}$ & $\frac{\overline{13}}{-}$ & $\begin{array}{r}8 \\
190 \\
3\end{array}$ & $\begin{array}{r}19 \\
187 \\
5\end{array}$ & $\begin{array}{r}1 \\
40 \\
2\end{array}$ & $\begin{array}{r}28 \\
430 \\
10\end{array}$ \\
\hline
\end{tabular}

Carretão

Pilão d'água

Monjolo

Máquinas Modernas

Aguia do Sul

Andrade

Aperfeiçoada

Arens \& Irmãos

Bernardino de Matos

Bierrenback

Brasileira

Concassor

Congresso

Duprat

Ferreira de Assis

Ferania

Fonseca

Hallier

Hargreaves

J. Jacintho de Mello

Lidgerwood

Mac-Hardy

Macedo

Manoel da C. Aguiar

Maravilha

Marinho \& Irmãos .

Mineira

Moderna

Progresso

Rocha Passos

Santa Cruz

Sistema Maucard

Triunfo

Valenciana

Vianna da Barra

Virginia

Vitória

Vitoriosa

Não declaradas

Ignoradas

\begin{tabular}{|c|c|c|c|c|}
\hline & & & & \\
\hline $\bar{z}$ & $\overline{9}$ & 1 & - & 1 \\
\hline$=$ & $\begin{array}{l}2 \\
1\end{array}$ & $\begin{array}{l}2 \\
4\end{array}$ & $\overline{1}$ & 4 \\
\hline - & 3 & I & 1 & $\begin{array}{l}0 \\
3\end{array}$ \\
\hline - & - & 1 & - & 1 \\
\hline & $=$ & 2 & - & 2 \\
\hline $\bar{z}$ & 6 & 17 & - & 23 \\
\hline I & 0 & 17 & $\overline{0}$ & 23 \\
\hline - & $\sqrt{2}$ & $\begin{array}{l}24 \\
26\end{array}$ & 2 & 26 \\
\hline- & 10 & 2 & $\bar{z}$ & $\begin{array}{l}28 \\
11\end{array}$ \\
\hline 1 & - & - & - & 1 \\
\hline 1 & - & - & - & 1 \\
\hline Z & $\overline{1}$ & 3 & - & 3 \\
\hline$E$ & 1 & Z & 二 & 1 \\
\hline 2 & 87 & 126 & 46 & 261 \\
\hline- & 一 & 7 & 2 & 2 \\
\hline- & - & 1 & - & 1 \\
\hline - & $\bar{z}$ & & $=$ & 2 \\
\hline- & 1 & & - & 3 \\
\hline- & 2 & 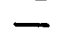 & - & 2 \\
\hline- & - & 20 & 4 & 24 \\
\hline - & $\overline{4}$ & 2 & 1 & 3 \\
\hline 1 & I & 10 & $\overline{3}$ & 14 \\
\hline- & 1 & - & - & 1 \\
\hline- & 7 & 3 & 2 & 12 \\
\hline- & 2 & 9 & - & 11 \\
\hline- & $=$ & $\begin{array}{l}4 \\
1\end{array}$ & $\overline{-}$ & 4 \\
\hline 1 & 1 & 3 & - & 5 \\
\hline & 3 & 2 & - & 5 \\
\hline- & 66 & 161 & 35 & 262 \\
\hline & & & - & \\
\hline 19 & 407 & 568 & 139 & 1.277 \\
\hline
\end{tabular}


Compreende-se com isto, em que pé se encontrava o beneficiamento do café, ante os fenômenos técnico-econômicos decorrentes da expansão da cafeicultura, do encarecimento do braço escravo e da insuficiência de mecanização de certas operaçōes. Pois bem, à ação dêsses fatores um havia de repercutir profundamente nas fazendas de café, colocando os seus donos num sério dilema. $\mathrm{E}$ tal fator outro não foi senão a "lei aurea" de 13 de maio de 1888. Golpe fortíssimo acabavam de receber as lavouras cafèeiras, as quais exigiam enorme quantidade de braços que outros não eram, no geral, senão escravos, e êstes, libertados, abandonavam as fazendas. Define-se bem a situação precária em que ficavam as fazendas, recordando a frase de Silveira Martins que salienta o papel do braço escravo nas mesmas - "O Brasil é o café e o café é o negro" (1).

$O$ agricultor que até essa época não mecanizara o seu beneficiamento teve que recorrer, às pressas, às máquinas então existentes. Com isto muito lucrou a indústria das máquinas de beneficiar café, a qual, recebendo vigoroso impulso, não tardou em apresentar inúmeros tipos. Mas é claro que nem tôdas triumfaram porque o agricultor, aprendendo a trabalhar com as mesmas, selecionou as mais eficientes. Coube à exigência do mercado compelir os fabricantes ao aperfeiçoamento destas e à construção de novas peças.

A evolução das máquinas de descarga contínua verificouse então sob o influxo de um complexo de fatores, tais sejam: as exigências dos cafeicultores, a influência precisa dos engenheiros-mecânicos, a concorrência entre as fábricas, as exposições de café, e principalmente, o gênio inventivo dos fabricantes. Chegaram assim essas máquinas ao estado atual, que não representa, é evidente, o ponto final do quanto pode fazer a técnica industrial pelo melhoramento e valorização do nosso produto.

\section{MAQUINAS DE ATUAL FABRICAÇAOO}

Com̌ a introdução dos fecundos conhecimentos técnico-agrários no terreno da cafeicultura, no sentido de melhorar as qualidades do produto, pouco a pouco tomou vulto a necessidade de encarar o beneficiamento como algo de importante que completa o ciclo das operações agrícolas. Daí terem-se aperfei-

(1) Bededicto Mergulhão - O General café na revolução branca de 37 - Pág. 31. 
çoado as novas máquinas, a-fim-de aprimorar as qualidades da preciosa semente, unindo inteligente e harmônicamente ao trabalho do campo o preparo do produto. A indústria passou então a cooperar com a cafeicultura. E hoje, graças a êsse adiantamento, o beneficiamento está notàvelmente melhorado. Com efeito, para o preparo do café existem atualmente inúmeros tipos de máquinas de constituição mais ou menos complexa que realizam um conjunto de operações.

Antes pois de empreendermos a citação da atual constituição das máquinas, é de grande utilidade, e também oportuno, citar prèviamente as operações que hoje constituem o Beneficiamento.

Marcha geral das operações - As máquinas de beneficiar café (consideramos apenas as de beneficiamento pròpriamente dito, por via sêca), realizam geralmente as seguintes operações (dizemos geralmente porque, em determinadas circunstâncias, podem deixar de reunir tôdas as que iremos mencicnar:

1.o) Transporte;

2.o) Limpeza;

3.0) Descascamento;

4.o) Ventilação;

5.o) Repasse;

6.o) Classificação;

7.o) Catação.

Infere-se do que foi exposto que o beneficiamento pròpriamente dito consiste :

No transporte do café em côco, da tulha à máquina. Na eliminação das impurezas, ou seja, limpeza (impròpriamente designada de desempedramento, visto que objetiva a separação de fôlhas, cascas, pedras, pauzinhos, torrões, café chocho, pregos, impurezas em geral. Em sequência, no trabalho do descascador, desmembrando o café em cascas (palha) e sementes (favas). O produto é então ventilado, separando-se a palha enquanto que o café pode ou não ser entregue ao Repassador ou Reparador para descascamento dos marinheiros e côcos. De passagem, é conveniente dizer que antigamente o café descascado e ventilado vinha a ser polido (brunido) em Polidores (Brunidores), o que em alguns casos era feito até com adição de plombagina ou oca, para a obtenção de produto de melhor aspecto ou mais brilhante. Hoje não se admite o café polido, pois, os compradores fazem questão da presença dos resíduos da película prateada (espermoderma), indício certo de que não sofreu o artificialismo do polimento (brunimento). Essa é a ra- 
zão por que as máquinas modernas podem apresentar Repassador, porém, não o Polidor ou Brunidor.

Retomando o fio das nossas considerações, logo após o repasse o café é entregue à ventilação para ser expurgado o resíduo da palha.

Descascado, repassado ou não, o café é conduzido para o classificador, que o separa em tipos concordes com o tamanho e o formato das favas ou sementes. Finalmente, por ventilação (catação-mecânica) separam-se, de cada tipo, os broqueados, chochos ou mal granados, quebrados, etc. (escôlha).

As operações se sucedem conforme especificamos, podendo todavia omitir-se esta ou oquela quando a qualidade do produto a beneficiar ou a obter, e a máquina, assim exigirem.

Constituição das Máquinas - De acôrdo com o que acabámos de ver, as máquinas são hoje constituidas, em geral de :

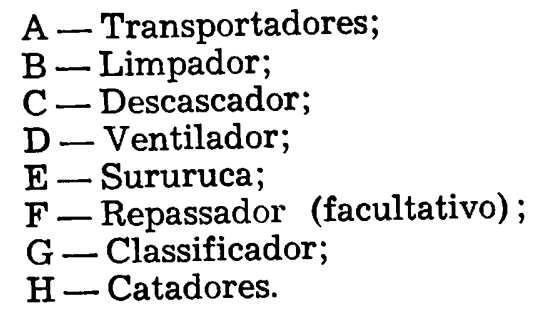

TRANSPORTADORES - A condução do café em côco, da tulha ao elevador de canecas da primeira peça da máquina, pode ser realizada hodiernamente por diferentes processos mecânicos de carga e descarga contínua. Dentre os transportadores utilizados para êsse fim, salientam-se os seguintes: 1.0) Bica de jôgo; 2.o) parafuso sem-fim que opera numa calha metálica perfurada, eliminando as impurezas ao mesmo tempo em que transporta o café; 3.o) raspadores que conduzem o café num canal retangular; 4.o) esteira sem-fim.

Predomina no Brasil o emprêgo da bica de jôgo.

Para o transporte do café da bica de jôgo à máquina, e entre as diversas partes da máquina utilizam-se elevadores de canecas.

LIMPADORES - Os limpadores atualmente empregados nas Máquinas de Beneficiar Café, não têm todos a mesma constituição, contudo sob o ponto de vista do processo mecânico em que se baseia o seu trabalho, podem ser classificados em três grupos fundamentais, a saber : 
1.o) Limpadores de ventilação;

2.o) Limpadores de peneiração;

3.o) Limpadores de ventilação e peneiração.

DESCASCADORES - O café separado das impurezas é conduzido pelo elevador ao Descascador.

O descascamento do café é a principal operação do beneficiamento, conforme se depreende do próprio histórico das máquinas de beneficiar café. Dada a importância dessa fase de beneficiamento, a peça responsável pela operação - o Descascador - é o coração das máquinas de beneficiar café, e do seu bom funcionamento e da sua duração é que depende a máquina.

Nas máquinas modernas o descascador está reunido geralmente ao ventilador, ou como em outras, agrega-se a êste de modo a formar quase uma única peça. Temos então nestes casos um Descascador-Ventilador.

Os descascadores que frizamos ser o coração das máquinas de beneficiar café - têm por função quebrar a casca do café em côco sem ofender de modo algum as sementes. De acôrdo com o princípio em que se baseiam, classificam-se em dois grandes grupos:

1.o) Descascadores de atrito;

2.0) Descascadores de pancadas ou choques.

1.o) DESCASCADORES DE ATRITO - Nas diferentes máquinas nacionais, são comuns os Descascadores construidos de forma a quebrarem a casca e o pergaminho do café, por efeito do atrito entre duas superfícies rugosas das quais uma, pelo menos, é móvel. Compreende-se que as disposições dos órgãos dêsse tipo de Descascador não são as mesmas em todos os representantes do grupo.

2.o) DESCASCADORES DE PANCADAS - Estes descascadores têm por função, que os define, desmembrar os grãos de café em palha e sementes mediante pancadas entre duas barras de aço.

A prática recomenda e a técnica exige que a distância entre as barras fixas e rotativas seja bem regularizada para evitar a quebra do café ou, em outras palavras, que se produza o chamado café bico de papagaio.

VENTILADORES - Oproduto proveniente do Descascador (considerando o caso em que a ventilação não se confunda com 
o descascamento) é um misto de sementes, marinheiros, palha e pó. A proporção de sementes varia com a qualidade do café em côco e de uma à outra máquina.

A separação da palha é feita então por meio de ventilação.

SURURUCA - O marinheiro é atualmente separado do café descascado, na maioria das máquinas, por uma peneira que realiza mecânicamente a operação de sururucar.

REPASSADORES - O café descascado e ventilado pode em sequência ser repassado.

A reparação ou o repasse consiste na ultimação do descascamento do marinheiro, café meio descascado, ou melhor café já trabalhado pelo descascador.

CLASSIFICADORES - A classificação do café resultou da concorrência comercial e da necessidade de conseguir-se maior homogeneidade na torração. Daí a introdução de nova prática no beneficiamento a qual veio satisfazer àquelas duas instâncias, ou seja a separação das sementes por diferença de tamanho e em obediência ao seu formato.

A separação do café por formato visa separá-lo, de acôrdo com a sua conformação, em dois grupos: chato e moca (encaracolado ou redondo). O café moca, originário do desenvolvimento anormal do fruto, é o resultante do desenvolvimento de um único óvulo numa semente, a qual então apresenta forma elipsoidal. O café chato é o produto do desenvolvimento normal do fruto, no qual, no ovário ínfero e bilicular formam-se duas sementes, que devido à disposição apresentam uma face plana e outra convexa.

Procede-se então a separação dêsses dois tipos de café por tamanho separando o moca em tipos de diferentes espessuras e o chato em tipos de diferentes larguras. Esta classificação racional e importante, além de proporcionar um meio de avaliação da homogeneidade do conjunto das sementes quanto ao tamanho e à forma, facilita a sua torração. Podemos comprovar que a separação citada influi favoràvelmente no andamento da torração, notando que, se o café empregado nesta operação não passou pela classificação, resulta ficarem as sementes pequenas, carbonizadas; as médias, torradas, e as grandes, apenas tostadas.

Foi reunindo essas e outras observaçöes, e com apôio no que o mercado exigia, que se desenvolveu a classificação inicial. A princípio as peneiras usadas nessa separação năo eram de calibração oficial, e por isso, classificava-se geralmente 0 
café em: chato-grôsso, chato-médio, moca, moquinha e cabeça, como se efetuava na máquina "Lidgerwood" e noutras então existentes, como por exemplo na máquina "Arens".

Quando o mercado norte-americano estabeleceu a calibração das peneiras e a Bolsa de Santos passou a adotá-la, nada mais restava aos fabricantes que introduzí-la nas peças de sua fabricação.

O café chato e o moca são hoje portanto classificados em vários tipos que passamos a examinar:

I - Café chato : A sua separação é feita atualmente em peneiras de furos circulares e de diấmetros exatamente estabelecidos em concordância com a padronização norte-americana. Classifica-se-o em vários tipos. Os tipos usuais são designados de chato $13,14,15,1617,18$ e 19, ou ainda, 20, 21 e 22.

A classificação do café chato nos tipos referidos dá a entender o seguinte: $O$ café chato 19 é constituído por sementes que vazaram a peneira de furos de $20 / 64$ polegadas, ou $7,9 \mathrm{~mm}$, de diâmetro, e ficaram retidas numa peneira de furos de 19/64", ou $7,5 \mathrm{~mm}$, ou melhor, peneira 19 . O chato 18 , vazado da peneira 19 é retido pela peneira 18, ou de furos de diâmetro igual a $18 / 64 "$, ou $7 \mathrm{~mm}$. O mesmo sucede para os $17,16,15,14$ e 13 , respectivamente.

II - Café moca : E' classificado em vários tipos, em peneiras de furos retangulares ou oblongos de comprimento geralmente constante, ou seja, $15 \mathrm{~mm}$ e largura variável. Destarte, o moca 12, por exemplo, é constituido por sementes elipsoidais que vazam da peneira de furos de $13 / 64^{\prime \prime}$, ou $5 \mathrm{~mm}$ de largura e ficaram retidas na peneira de crivos de $12 / 64^{\prime \prime}$, ou $4,7 \mathrm{~mm}$ de largura. Cousa semelhante se passa com o moca $11,10,9$ e 8 , correspondentes às peneiras de furos de larguras de 11/64", 10/64", 9/64", 8/64", respectivamente.

No que diz respeito aos tipos fornecidos pelas máquinas, êles variam de acôrdo com o café e o tipo de máquina.

Apresentada a classificação em tipos, fácil é agora observar que as dimensões dos furos das peneiras variam de um fator constante, ou seja, de $1 / 64 "$, ou $0,4 \mathrm{~mm}$.

Infere-se também do exposto que se separa o café chato do moca em peneiras de furos retangulares ou oblongos, nas quais o chato vaza, e o móca fica retido.

Acrescenta-se ainda que se encontram nas máquinas modernas dois tipos de café : o Cabeça e o Fundo. O Cabeça é o café retido pela peneira de furos de maior diâmetro e o Fundo é cons- 
tituido por sementes que vazaram as peneiras de furos de menor diâmetro.

Do estudo geral da classificação do café infere-se que o Classificador tem como órgão essencial um conjunto de peneiras. $\mathrm{E}$ de acôrdo com a constituição dêstes órgãos dividem-se em dois grupos :

A) - Classificadores de peneiras cilíndricas ou rotativas : Separadores.

B) - Classificadores de peneiras planas: Monitores.

A) SEPARADORES - A classificação do café no Brasil teve início em Classificadores-Separadores. O órgão classificador das máquinas primitivas era constituido por um longo tubo de cobre (de uns seis metros mais ou menos), de grande diâmetro, punçado, no qual se sucediam diferentes séries de furos constituintes das diversas peneiras conjugadas. Disposto com suave declive numa armação de peroba êste tubo podia girar com pequena velocidade. Com o desenvolvimento apresentado pela cafeicultura e ante o volume crescente de sua produção, êsse Classificador veio experimentando modificações até originar o tipo atual.

B) MONITORES - Os classificadores de peneiras planas, embora seja de aplicação mais recente (foram introduzidos pelas máquinas norte-americanas então importadas), e agora predominam entre os classificadores das máquinas nacionais. Constam de um ou mais conjuntos de peneiras planas, animadas de movimento retilíneo alternativo.

CATADORES - A catação tem por objetivo eliminar por ventilação o café chocho, quebrado, etc., (escôlha e repasse), a fim de se obter um produto bom, ou evitar o trânsito dêsse café pelo classificador, o que aumenta o rendimento da peça. Consta pois de uma coluna de vento, onde por diferença de densidade separaram-se os produtos.

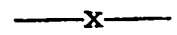

Temos assim concluido a citação geral das peças componentes das atuais Máquinas Nacionais. Resta-nos ainda dizer que estas podem ser conjugadas de diferentes modos (por ex.: Descascador-ventilador, separador-catador etc.), porém, recain- 
do sempre num dos seguintes conjuntos de máquinas de beneficiar café :

a) Máquinas conjugadas;

b) Máquinas combinadas.

MAQUINAS CONJUGADAS - São aquelas nas quais as peças que as compõem são separadas uma das outras. Dêste modo, os órgãos constituintes de uma destas máquinas podem ser do mesmo ou de diferentes fabricantes. Dada a disposição linear de suas peças, ocupam uma extensão de alguns metros.

MAQUINAS COMBINADAS - Tendo em mira atender a pequena cafeicultura ou às pequenas produções, os fabricantes foram impelidos à construção de máquinas que oferecessem os seguintes característicos de órdem técnico-econômica : exigência de menor potência, redução das transmissões, exigência de menor construção para sua instalação, enfim, menor custo.

Tal objetivo foi atingido pela reunião das peças num bloco único. As máquinas assim construidas que apareceram pela primeira vez no Brasil em 1908 receberam o nome de máquinas combinadas.

Existe hoje pris, em funcionamento, um grande número de fábricas nacionais de Beneficiar Café, que produzem máquinas de tipos e dimensões as mais variáveis, de constituição bem acabada, que sofrendo a concorrência das fábricas estrangeiras, são vendidas em outros países produtores de café.

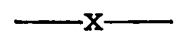

Finalmente, encerrando, diremos, conforme observamos de tudo que foi exposto, a evolução das Máquinas de Beneficiar Café foi no Brasil rápida e precisa, como inicialmente afirmamos. O árduo trabalho de descascamento manual no qual o laborioso escravo podia sòmente descascar diàriamente alguns quilogramas de café, foi transformado no suave trabalho de dirigir as modernas máquinas, que, movidas a motor elétrico, podem fornecer em 10 horas de funcionamento mais de 30.000 quilogramas de produto devidamente descascado, catado e classificado. Desta forma pôde a indústria nacional, o que é uma satisfação constatar, atender a cafeicultura a fim de que o nosso produto básico pudesse sofrer tôda luta comercial, e continuar a ser o esteio da economia do nosso país. 


\section{BIBLIOGRAFIA}

1 - A cultura do café - Publ. do Ministério da Agricultura - Rio de Janeiro - 1929. Págs. 51-52.

2 - A ifluência da colheita e do preparo na luta pela obtenção de cafés de finas qualidades - O campo. N. de outubro de 1937.

3 - AGUIAR, Padre João Joaquim Ferreira de - Pequena memória sôbre a plantação, cultura e colheita do café Ed. Imprensa Americana de I. P. da Costa - Rio de Janeiro. - 1836. Pág. 14.

4-ANTONIL, André João - Cultura e opulência do Brasil por suas drogas e minas - Ed. Companhia de Melhoramentos de São Paulo - São Paulo - 1923. Pág. 116.

5-Aspectos da economia rural brasileira - Publ. do Ministério da Agricultura - Rio de Janeiro - 1922. Pág. 196.

6- ASSIS Cintra - Origem do Maquinário do café - Revista do Instituto do Café - São Paulo - N. de dezembro de 1935. Pág. 2.584.

7 - Os primeiros cafesais e as primeiras máquinas de café de São Paulo - Boletim da Máquina "São Paulo" - Limeira - N. de dezembro de 1935 e janeiro de 1936. Pág. 8.

8-BERNEGG, Sprecher van - Plantas tropicais e sub-tropicais da economia universal - Ed. Departamento Nacional do Café - Rio de Janeiro - 1838. Pág. 242.

9 - Colheita e beneficiamento dos grãos de café - Revista do Departamento Nacional do Café - Rio de Janeiro - N. de dezembro de 1939. Pág. 771.

10 - BROCA, Jacques Pierre - A classificação comercial do café - Boletim da Máquina "São Paulo" - Limeira N. de julho de 1936. Pág. 3.

11 - - A classificação comercial do café - Boletim da Máquina "São Paulo" - Limeira - N. de outubro e novembro de 1936. Pág. 5.

12-BROWN, F. J. - Notas sôbre o beneficiamento do café Revista La Hacienda - N. York — N. de janeiro de 1917. Pág. 119.

13 - BURLAMAQUE, F. S. L. - Monografia do cafeseiro Ed. Tipografia Vianna \& Filhos - Rio de Janeiro - 1860. Pág. 40.

14 - CARRILLI, Jaime F. - Memoria sôbre el beneficio del café - Ed. Carlos Espinal - N. York - 1882. Pág. 3. 
15 - CARVALHO Araujo, Bernardo Sayão de $-A$ evolução do beneficiamento - Revista "O café" - São Paulo - N. de junho de 1932. Pág. 152.

16 - CARVALHO Rarbosa, J. - A história do café - Revista "O café" - São Paulo - N. de março de 1931. Pág. 92.

17 - CASTRO, Florentino - A minha experiência sôbre beneficiamento do café - Revista do Departamento Nacional do Café - Rio de Janeiro - N. de julho de 1936. Pág. 54.

18 - CASTRO, Lyra - A trajetoria histórica do café - O café no segundo centenário de sua introdução no Brasil 1.o Volume - Ed. Departamento Nacional do Café - Rio de Janeiro - 1934. Pág. 48.

19 - Concassor de café - Nova máquina de preparar café Ed. Tipogr. Moreira Maximino \& Cia. - R. de Janeiro. 1875.

20-CONSTANT, G. - Do café, considerado no sentido de sua colheita, de sua lavagem e da sua maneira de secá-lo para o comércio - Ed. Tip. Francesa - Rio de Janeiro. 1843.

21-COSTA Ferreira, Ruy da - Evolução do preparo industrial do café - Revista do Departamento Nacional do Café - Rio de Janeiro - N. de Agosto de 1936. Pág. 243.

22 - - Defeitos, impurezas e bebida - Boletim da Superintendência dos Serviços do Café - São Paulo - N. de setembro de 1943. Pág. 706.

23 - COSTA Santos, Horácio Alexandrino da - Breves considerações sôbre o nosso café - Ed. Tipogr. de G. Leuzenger \& Filhos - Rio de Janeiro - 1881. Pág. 10.

24-COUGARD - D'Aulnay, G. E. - Monographie du café -. Ed. Mme. Ve Bouchard - Huzard - Paris, 1843. Págs.

25-Cultura cafeeira em Minas Gerais - Boletim do Ministério da Agricultura - Ano XVI, vol. II, n. 3 - Rio de Janeiro. 1927.

26 - Cultura de café no Brasil - (Ensáio de corografia estatística). Levantamento de 1940-41. - Ed. do Departamento Nacional do Café - Rio de Janeiro. 1941.

27 - Cultura de café no Brasil - (Ensáio de corografia estatística) - II - Estado do Paraná - Ed. do Departamento Nacional do Café - Rio de Janeiro. 1941.

28 - Cultura do café - Boletim do Ministério da Agricultura Ano XVI, vol. II, n. 3 - Rio de Janeiro, 1927.

29 - DELDEN Laèrne, C. F. van - Le Brasil et Java. Rapport sur la culture du café - Ed. Martinus Nyhoff - Haia. 1885.

30 - E. TAUNAY, Affonso de - Notas ligeiras sôbre os primórdios da lavoura cafeeira em São Paulo - Revista "O café" - São Paulo - N. de maio de 1931. Pág. 17. 
31 - - Beneficiamento dos cafés coloniais - Revista do Instituto Nacional do Café - Rio de Janeiro - N. de dezembro de 1935 - Pág. 2.564.

32 - - Subsídios para a história do café no Brasil - Ed. Departamento Nacional do Café - Rio de Janeiro - 1935. Pág. 414.

33 - - História do café no Brasil - Volume segundo - Ed. Departamento Nacional do Café - Rio de Janeiro - 1939. Pág. 378.

$34-1-$ História do café no Brasil - Volme quinto Ed. Departamento Nacional do Café - Rio de Janeiro 1939. Pág. 103.

35 - - História do café no Brasil - Volume sexto - Ed. Departamento Nacional do Café - Rio de Janeiro - 1939. Págs. 16 e 46.

36 - - História do café no Brasil - Volume sétimo - Ed. Departamento Nacional do Café - Rio de Janeiro 1939. Pág. 224.

37 - El café - su historia, cultivo, beneficio, etc. - Ed. La Oficina International de las Republicas Americanas - Washington D. C. - 1902. Pág. 25.

38 - FAUCHERE, A - Culture pratique du caféier et preparation du café - Ed. Augustin Challamel - Paris - 1908. Pág. 75.

39 - - Le café - Prodution, preparation et commerece - Ed. Société D'Editions Geografique, Martimes et coloniales - Paris - 1927. Pág. 98.

40 - FERREIRA Rangel, Silvio - O café - Publi. da Sociedade Nacional de Agricultura - Rio de Janeiro, 1908. Pág. 69.

41 - FERREIRA Velloso, José - Benefício do café - Revista "O café" - São Paulo - N. de junho de 1932. Pág. 174.

42 - FONSECA Queiroz, Joaquim Silverio de - Informações úteis sôbre a cafeicultura - Ed. Estabelecimento Gráíicco "Universal" - São Paulo - 1914. Págs. 159 e 165.

43 - Jornal do Agricultor - Ed. Dias da Silva Júnior - Rio de Janeiro - N. do ano de 1879.

44 - KERMANS e Laliére - Le café - 1.0 volume - Paris 1931. Pág. 179.

45-LALIERE, A - Le café dans l'etat de Saint Paulo (Brésil) - Ed. Augustin Challamel - Paris, 1909. Pág. 161.

46- LECOMTE, Henri - Le café - Culture, Manipulation, - Ed. Carré et Naud - París - 1889. Pág. 139.

47 - LISBOA, J. C. Belo - Classificação racional do café Boletim da Secretaria da Agricultura, Indústria e Comércio do Estado de São Paulo - 1928. 
48 - MAGALHAES, Hildebrando de - História do café - Ed. Tipografia do Jornal de Piracicaba, 1934. Págs. 116 e 128.

49 - MARQUEZ, Nelson - "O preparo para o mercado ou beneficiamento do café - Revista do Departamento do Café - N. de agôsto de 1936. Pág. 243.

50 - MERCADO, Jorge - A bica de jôgo - Revista "O café" - São Paulo - Ano II - N. de abril de 1932. Pág. 35.

51 - MERGULHÃO, Benedicto - A santa inquisição do café - Ed. Irmãos Pongetti - Rio de Janeiro, 1940. Pág. 166.

52 - - O general café na revolução branca de 37 Ed. Irmãos Pongetti - Rio de Janeiro, 1943.

53 - MIRANDA, Raphael P. de - Cultura do café na Bahia Ed. Papelaria Brasileira - Bahia, 1922. Pág. 66.

54 - MORAIS Campanelli, Derisdedit - O café na Bahia Boletim da Máquina "São Paulo" - Limeira - N. de janeiro e fevereiro de 1937. Pág. 27.

55 - MOREIRA, Nicolau Joaquim - Breves considerações sôbre a história e cultura do cafeeiro - Ed. Tipog. do Imperial Instituto Artístico - Rio de Janeiro, 1873. Pág. 49.

56 - MOREIRA, Nicolino - Maquinismo para beneficio de café - Revista "O café - São Paulo - Ano I - N. de fevereiro de 1931. Pág. 44.

57 - O Auxiliador da Indústria Nacional - Periódico da Sociedade Auxiliadora da Indústria Nacional - Ed. Tipog. Universal - Rio de Janeiro - Vol. XX, 1853.

58 - O Auxiliador da Indústria Nacional - Periódico da Sociedade Auxiliadora da Indústria Nacional - Ed. Tipog. Universal - Rio de Janeiro - Vol. XXXVIII, 1868.

59-O Auxiliador da Indústria Nacional - Periódico da Sociedade Auxiliadora da Indústria Nacional - Ed Tipog. Universal - Rio de Janeiro - Vol. XL, 1872.

60 - OKERS, William H. - All obout coffee - New York 1922.

61 - OLIVEIRA FILHO, M. Lopes de - O preparo do café Publ. da Secretaria da Agricultura, Indústria e Comércio do Estado de São Paulo - 1928.

62-PESTANA, Paulo R. - O café em São Paulo (notas históricas) - Pub. da Secretaria da Agricultura, Indústria e Comércio do Estado de São Paulo - São Paulo, 1927. Pág. 13. 
63 - PIETTRE, M. Maurice - Production industrielle du café - Ed. Libraire E. Le François - Paris, 1925. Pág. 118.

64-PORTO ALEGRE, Paulo - Monografia do café, história, cultura e produção - Ed. Bertrand - Lisbôa, 1879. Pág. 122.

65 - RAMOS, Augusto - O café no Brasil e no extrangeiro Ed. Papelaria Santa Helena - Rio de Janeiro, 1923. Pág.173.

66 - - Máquinas primitivas de beneficiar café O café no Segundo Centenário de sua introdução no Brasil - 1.0 volume - Ed. Departamento Nacional do Café — Rio de Janeiro, 1939. Pág. 75.

67 - Relatório da Segunda Exposição de Café no Brasil Centro de Lavoura e Comércio - Ed. Tipog. e Litog. de Moreira Maximino \& Cia. - Rio de Janeiro, 1883.

68 - RODRIGUES CUNHA, Augustinho $-A$ arte da cultura e preparação do café - Ed. Tipog. Universal de Laemmert — Rio de Janeiro, 1844. Pág. 88.

69 - SMITH, Herbert Huntington - Uma fazenda de café no tempo do Império - Ed. Departamento Nacional do Café — Rio de Janeiro, 1941. Pág. 13.

70 - TEIXEIRA de Oliveira - Vida maravilhosa e burlesca do café - Ed. Companhia Editora Americana - Rio de Janeiro, 1942.

71 - VILLARES, Jorge Dumont - O café, sua produção e exportação - Ed. Instituto do Café do Estado de São Paulo - São Paulo, 1927. 1.0 e 2.0 volume.

72-ZALUAR, Augusto Emilio - Exposição Nacional Brasileira de 1875 - Ed. Tipog. do Globo - Rio de Janeiro, 1875.

73 - ZIMMERMANN, A. - O café - Ed. do Departamento Nacional do Café - Rio de Janeiro, 1933. Pág. 112. 


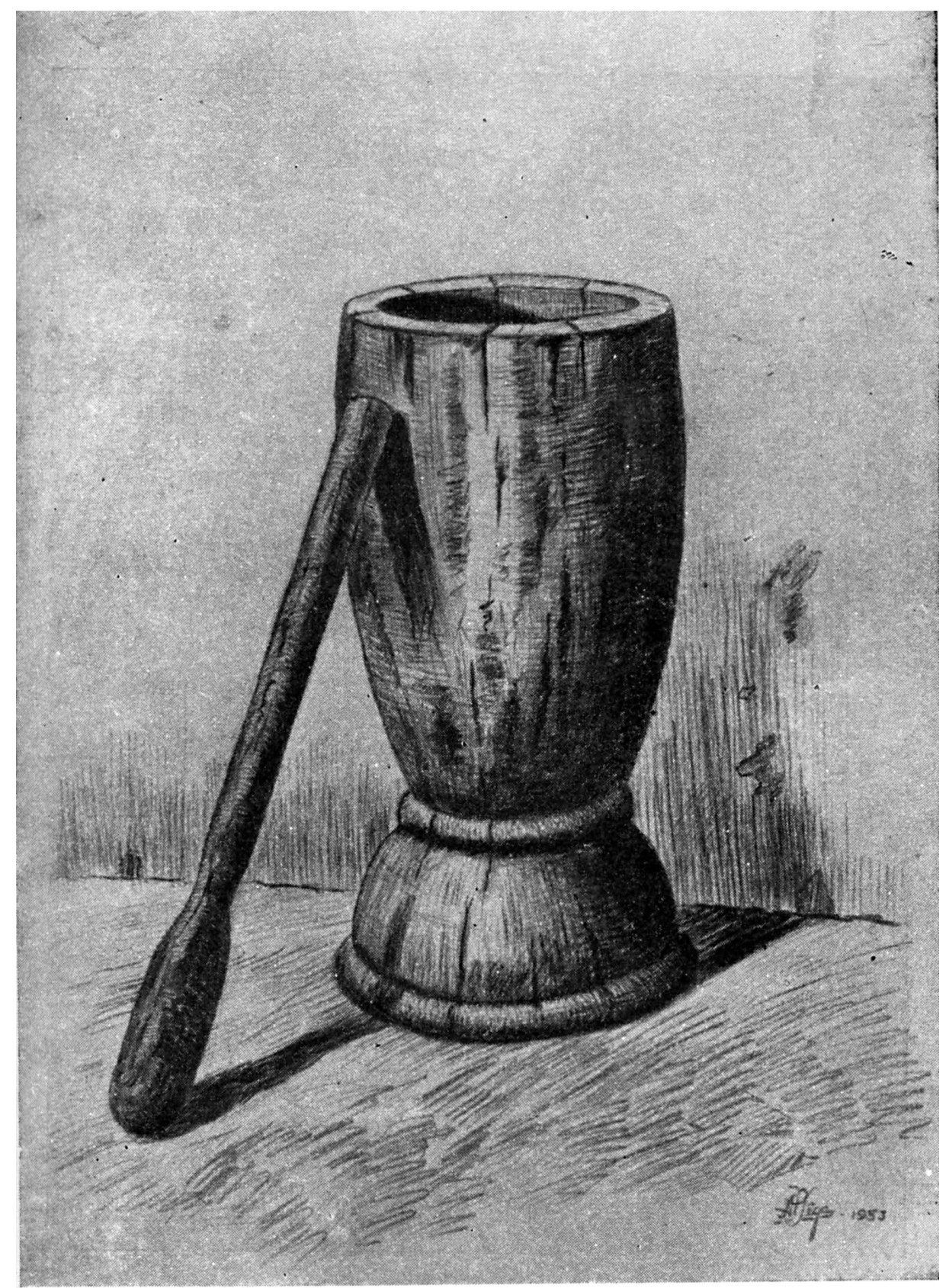

Fig. 1 - Pilão 


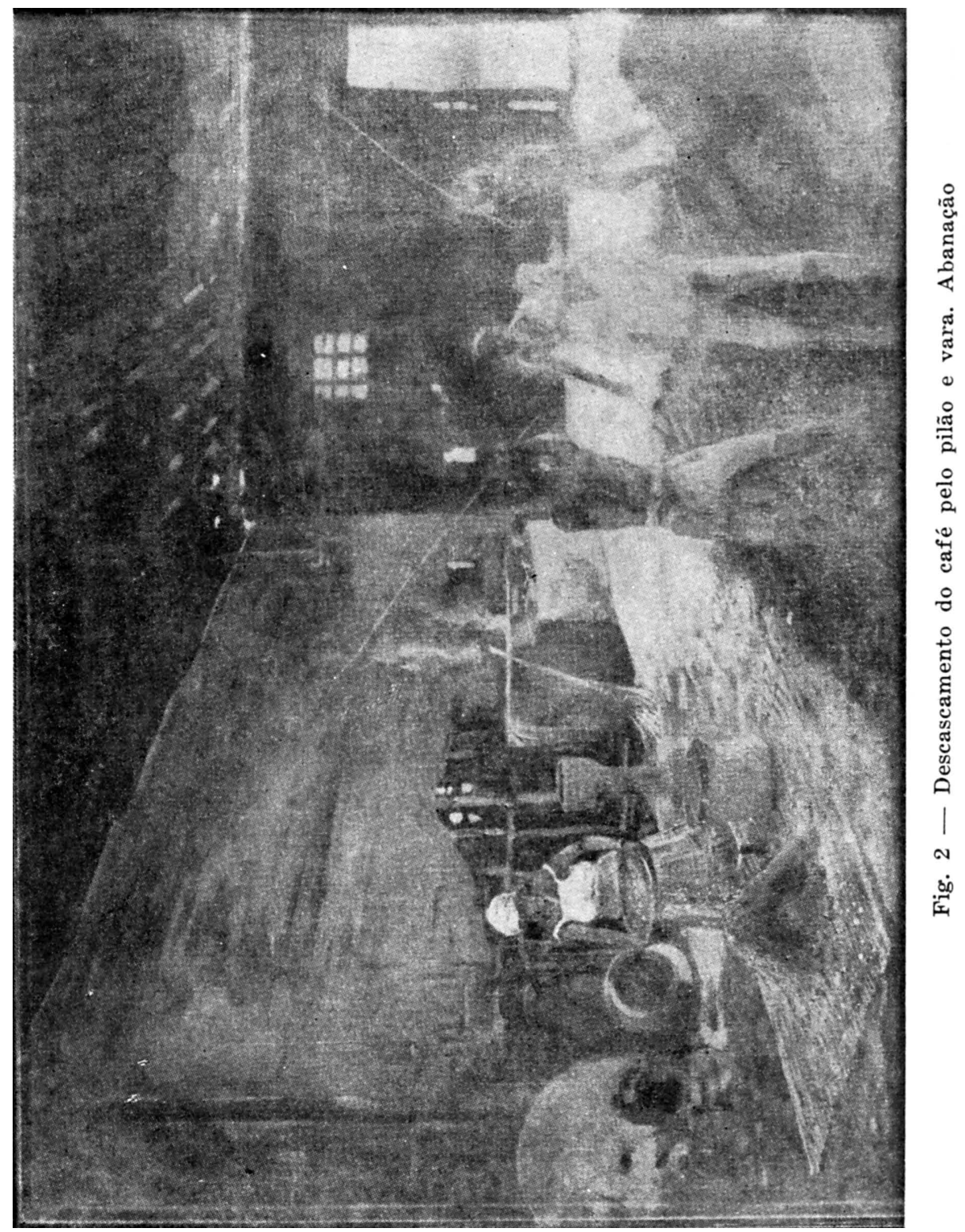




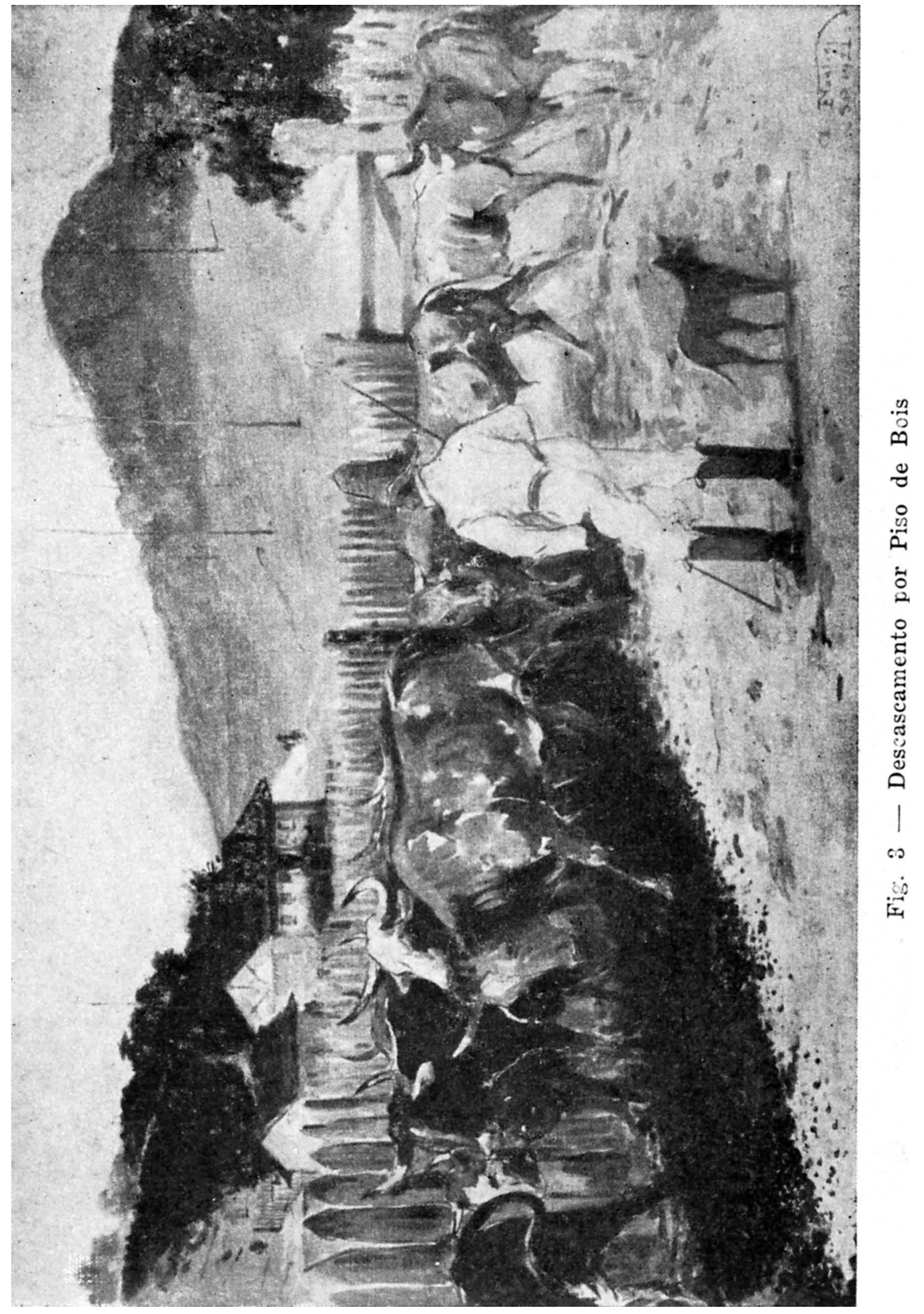




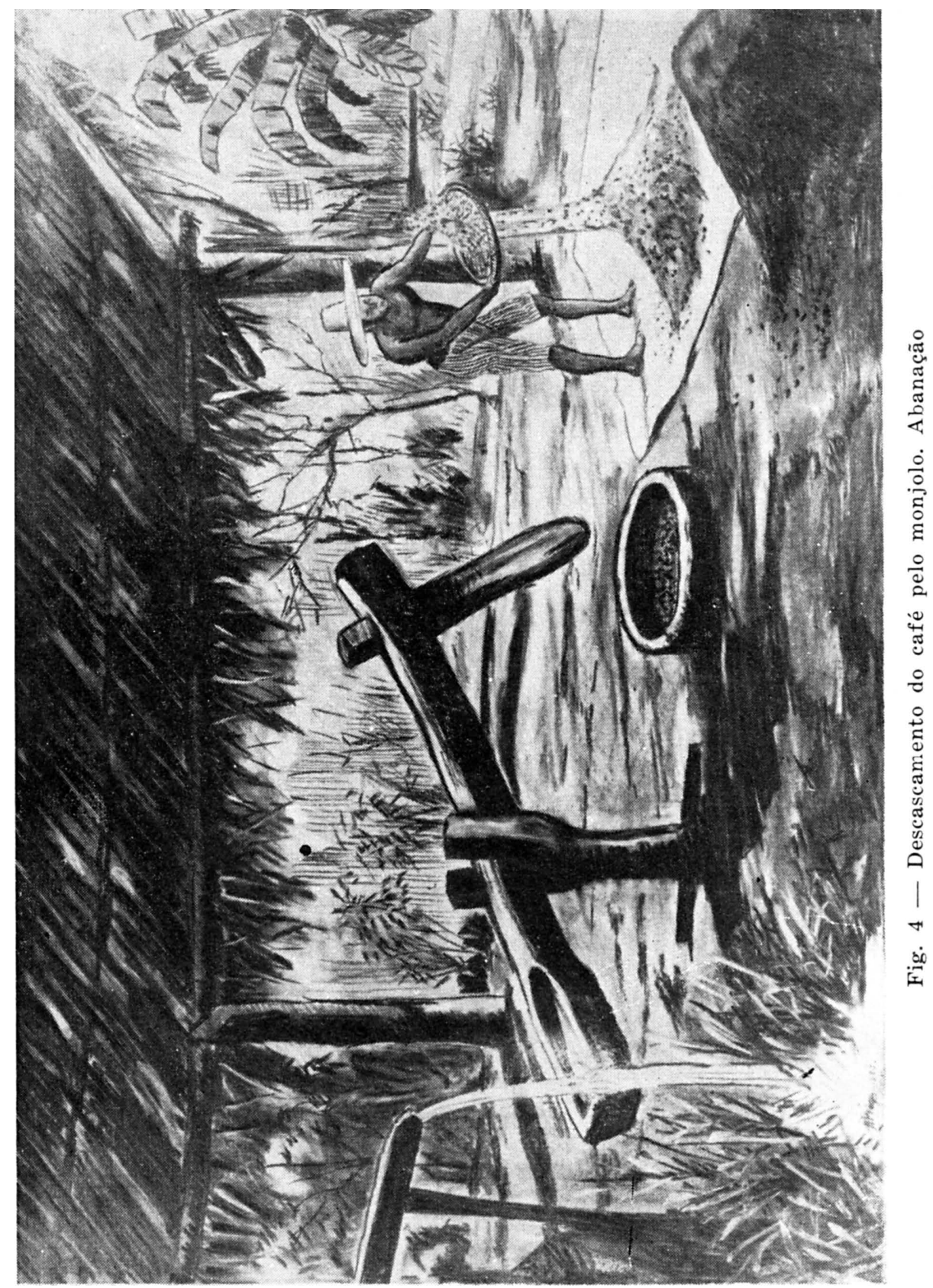




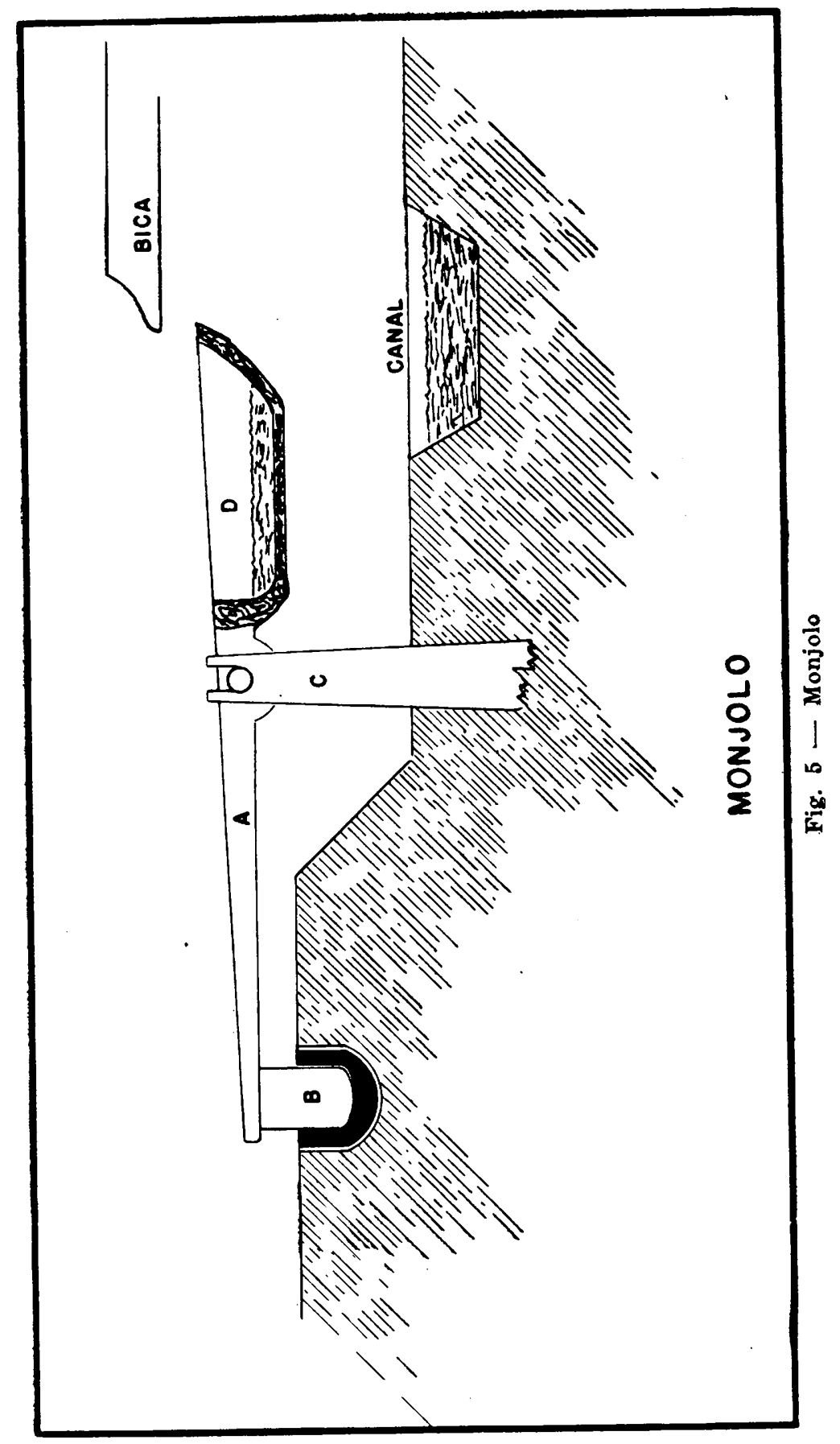




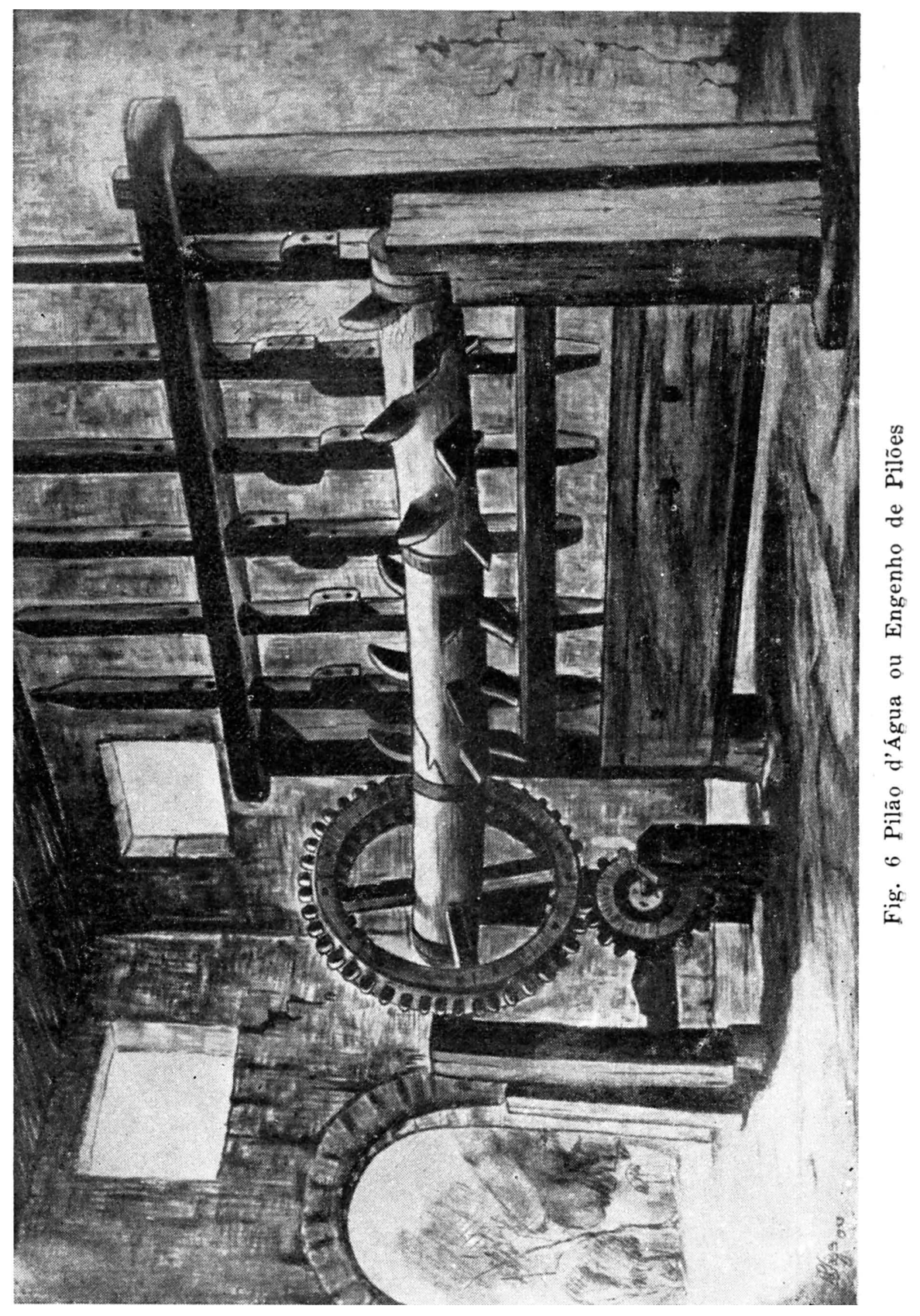




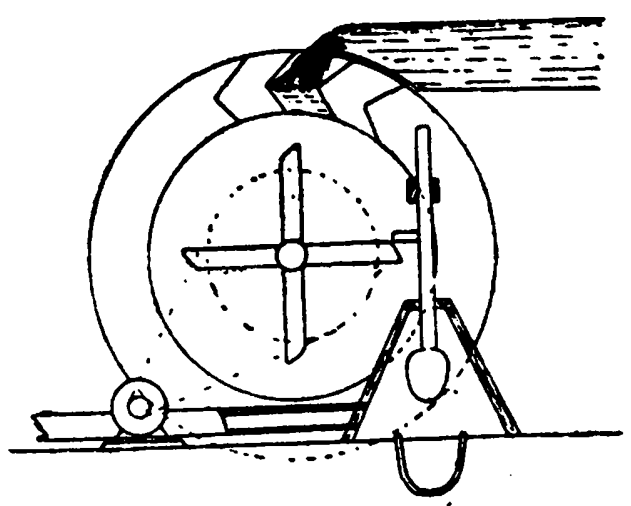

Fig. 7 a - Pilào d'Águá

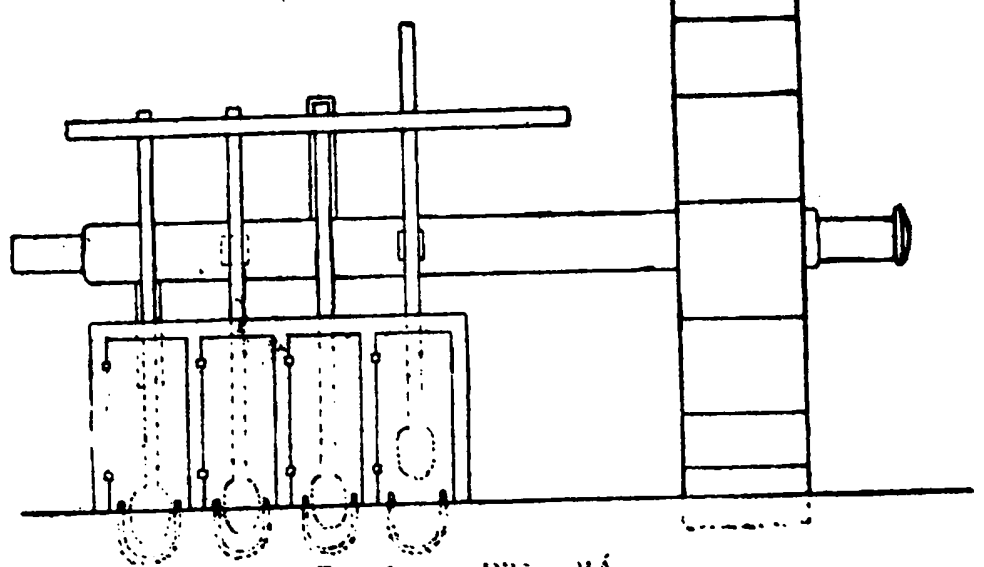

Fig. 7 o - Pilio d'Água 


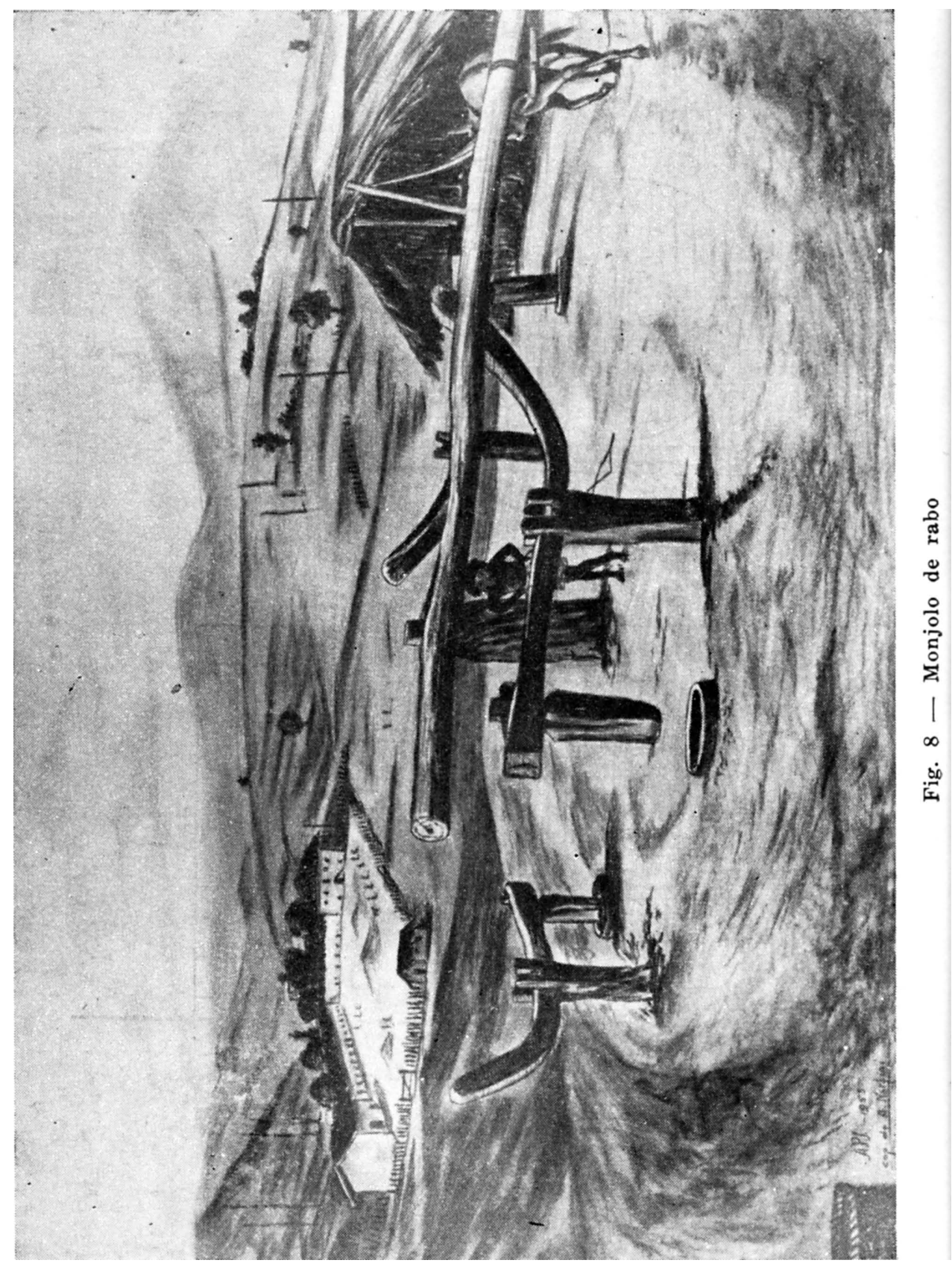




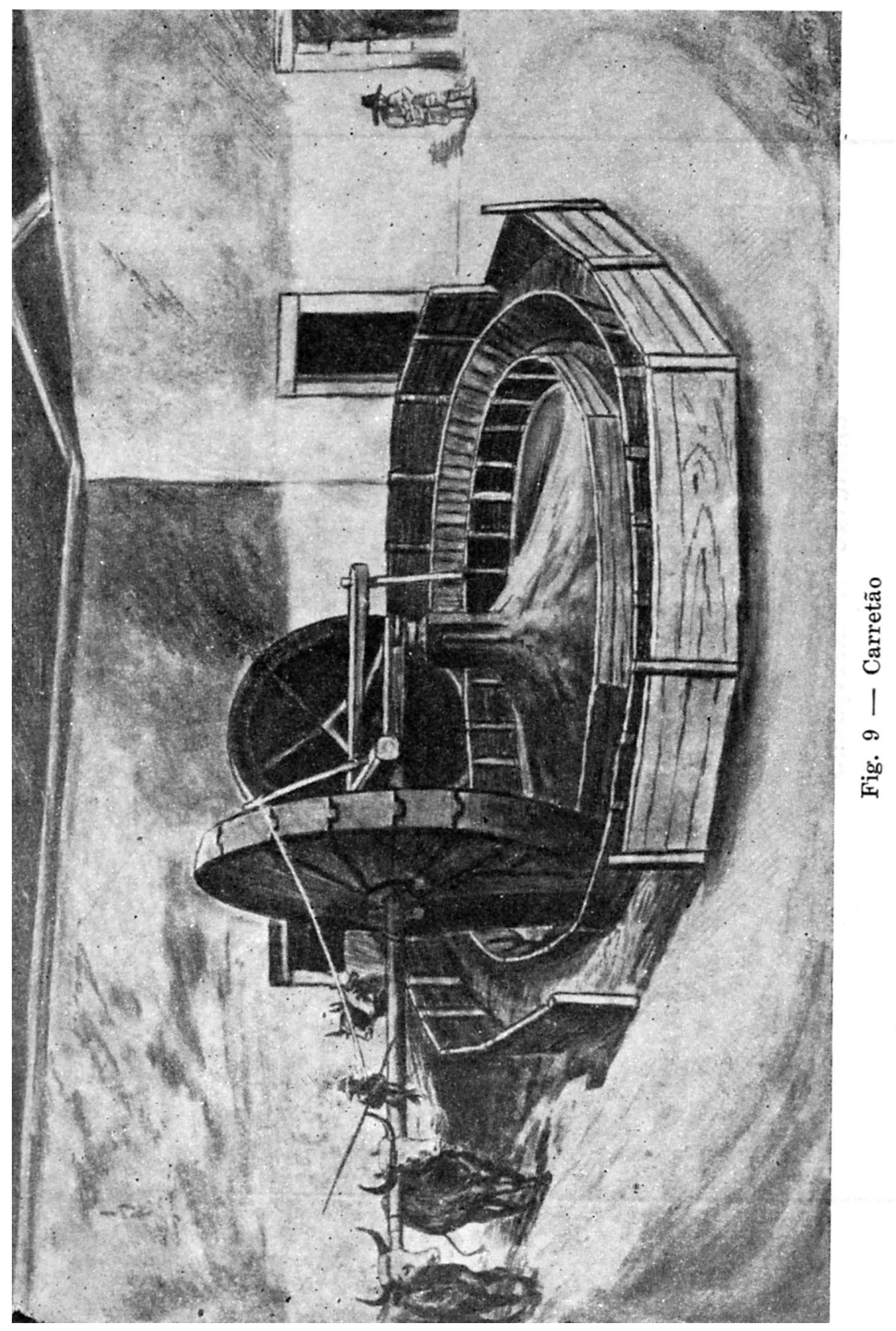




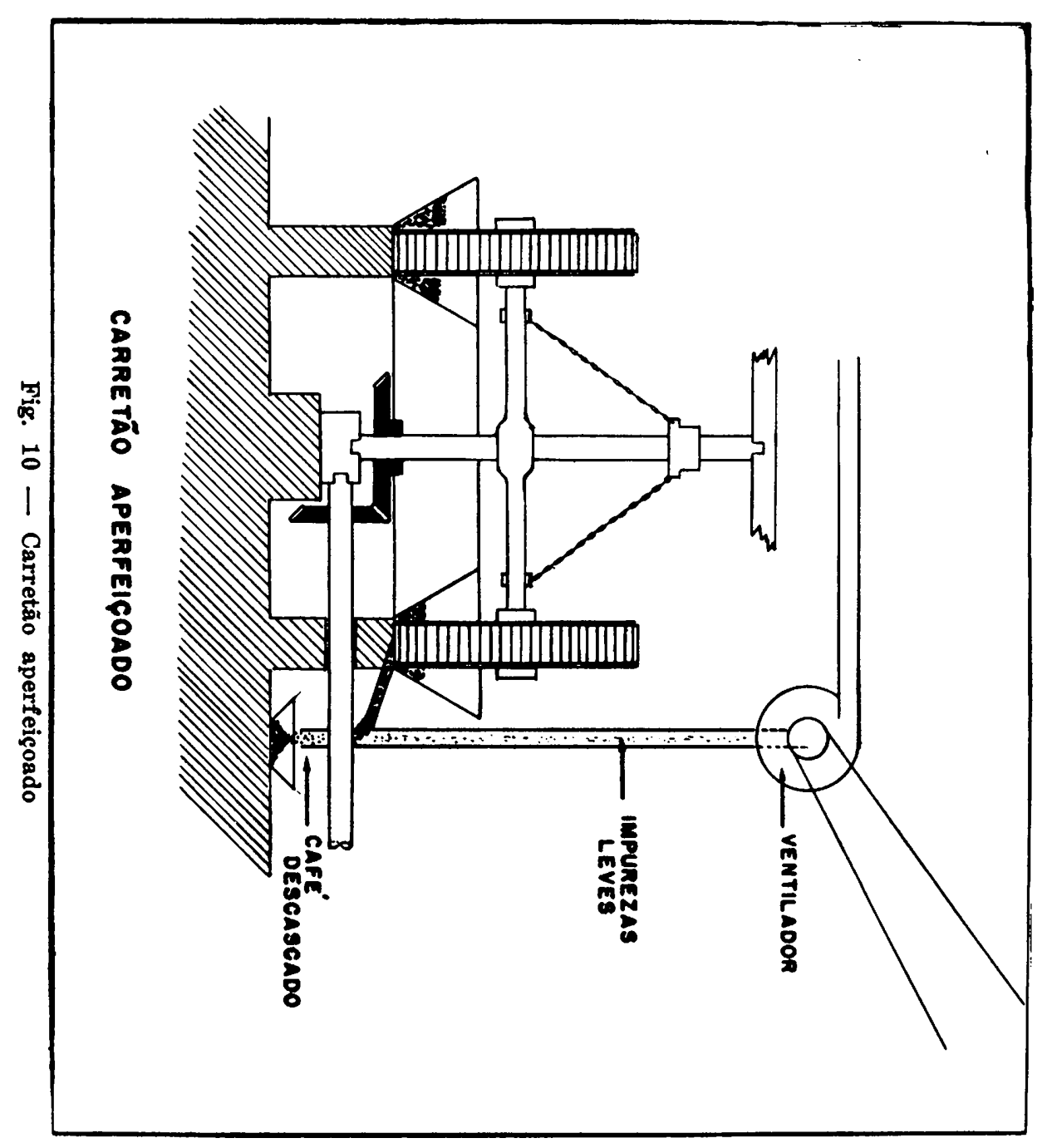

